\title{
Dynamics of serious pest of Metopolophium dirhodum (Walk.) (Hemiptera: Aphididae) on shrubs of Rosa rugosa Thunb.
}

\author{
ROBERT KRZYŻANOWSKI
}

\author{
Siedlce University of Natural Sciences and Humanities \\ Department of Biochemistry and Molecular Biology \\ B. Prusa 12 \\ 08-110 Siedlce, Poland \\ e-mail: robert.krzyzanowski@uph.edu.pl
}

\section{Summary}

Introduction: Rose grain aphid (Metopolophium dirhodum Walk.) is one of the most important pests on cereals in Poland. The economic importance of this pest has increased in recent years due to the increase in the area of maize cultivation. M. dirhodum is an oligophagic aphid feeding also on different rose species.

Objective: The purpose of the present study was to evaluate the dynamics of population of $M$. dirhodum on the saltspray rose.

Methods: The studies were conducted on saltspray rose stands at Aleksandria Park in Siedlce in 2005-2009. At each selected stand, 50 rose shoots were observed every 7 days from March to spring migration of the aphid.

Results: First fundatrices of the $M$. dirhodum on the R. rugosa were observed at the end of March. The rosegrain aphid population development on the primary host during May, and reached maximum population in the middle of May. During autumn, the aphid backed for overwintering on the primary host.

Conclusion: While the $M$. dirhodum population outbreaks, the aphid might be a serious pest of the saltspray rose.

Key words: rose grain-aphid, Metopolophium dirhodum, saltspray rose, Rosa rugosa, aphid pest dynamics

\section{INTRODUCTION}

Saltspray rose (Rosa rugosa Thunb.) is a suckering shrub native to North-east Asia, including northern Japan (Hokkaido and Honshu down to $35^{\circ} \mathrm{N}$ ),
Korean, NE China (Liaoning and Shandong provinces) and Russian Far East (Kamchatka up to $55^{\circ} \mathrm{N}$, Sakhalin, Kuriles, Khabarovsk region and Primorye region). It was introduced independently from the Far East to Europe and North America, in the late 
$18^{\text {th }}$ century and around 1845 , respectively. From the beginning of the $20^{\text {th }}$ century, it was extensively planted along roads and railways with sandy embankments and near summer cottages, both in Europe and North America [1, 2]. Darbyshire [3] in North America reported it in 19 states in USA. Due to the presence of secondary metabolites exhibiting pharmacological activity, the flowers of $R$. rugosa are applied in traditional and folk medicine. The essential oils obtained from them are also considered to be phytoncides [4]. Petals of the R. rugosa flowers are valued as raw material, while rose oil [5, 6], is used in health therapy instead of fruits [7]. In China, where this species is found in natural stands, flower buds and petals, after drying, are used to produce herbal tea [5, 8-9]. Flavonoids, anthocyanins, tannins, and essential oil, whose main constituents are geraniol, citronellol and nerol are present in rose flower tissues $[5,10]$. Moreover, flower decoction is used as an agent for activating blood circulation to relieve blood stasis as well as in indigestion and for wounds due to its anti-inflammatory and astringent effects $[7,11]$. The flowers of $R$. rugosa are also used as an agent counteracting toxins, among others as an antidote in antimony intoxication, improving appetite and function of kidney. It has been also shown that rose oil can be included in active phytoncides affecting microorganisms resistant to antibiotics [4-5].

The roots of $R$. rugosa have been traditionally used to treat diabetes mellitus, pain, and chronic inflammatory disease in Korea. Previously, the hypoglycemic factor such as catechin, was isolated from their tissues together with triterpenoids, along with 28-glucosides of euscaphic, tormentic, and arjunic acids. On the other hand, triterpenoids with antinociceptive/antiinflammatory action, e.g., oleanolic acid, momordin Ic, hederagenin, kalopanaxsaponin A, and 23-hydroxyursolic acid, were reported [12].

In last few decades, aphids have become serious agricultural pest in temperate climatic zones, significantly reducing crop yields and quality. Their direct negative influence is bound to mechanical injury of plant cells and disturbance of metabolism within the infested plants $[13,14]$. In Central Europe, holocyclic populations are usually dominant in most seasons, yet anholocyclic clones are rare [15].

The occurrence of rose-grain aphid ( $M$. dirhodum) was observed also on saltspray rose [16] and dog rose [17]. Blackman and Eastop [18] reported that apterae morphs are major aphid pest on saltspray rose. They are elongated spindle-shaped, and are of green or yellowish-green colour, with a distinct brighter green longitudinal mid-dorsal stripe.
Their antennae are mainly pale with apices of III$\mathrm{V}$ segments, VI segment near the primary sensoria, and the terminal process dusky is black. Legs, siphunculi and cauda pale. However, alatae (1.6$3.3 \mathrm{~mm}$ ) have a green abdomen without dorsal abdominal markings.

This aphid species feeds in summer on several species of grasses and on roses in winter, including $R$. rugosa. The purpose of present paper was to evaluate the population dynamics of $M$. dirhodum occurring on the saltspray rose.

\section{MATERIAL AND METHODS}

The studies were conducted on saltspray rose bushes (Rosa rugosa Thunb.) growing at Siedlce in 20052009. The saltspray rose sites were selected for the study at Aleksandria Park, located in the central part of the town.

For each of selected stands, samples of 50 shoots were analyzed. The observations were carried out every 7 days from the beginning of March until the spring migration of the aphid alates (fig. 1-2). All morphs of the pest as were identified according to Blackman and Eastop [6]. The results were expressed as an average number of aphids per shoot.

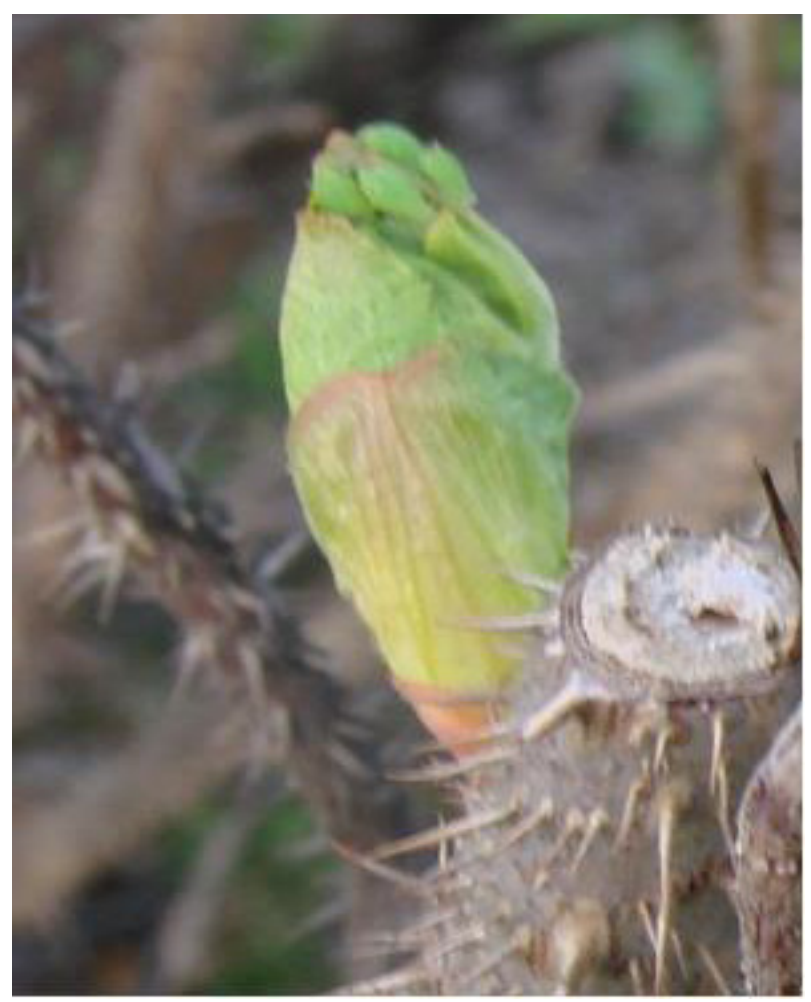

Figure 1.

First fundatrices of $M$. dirhodum on saltspray rose 


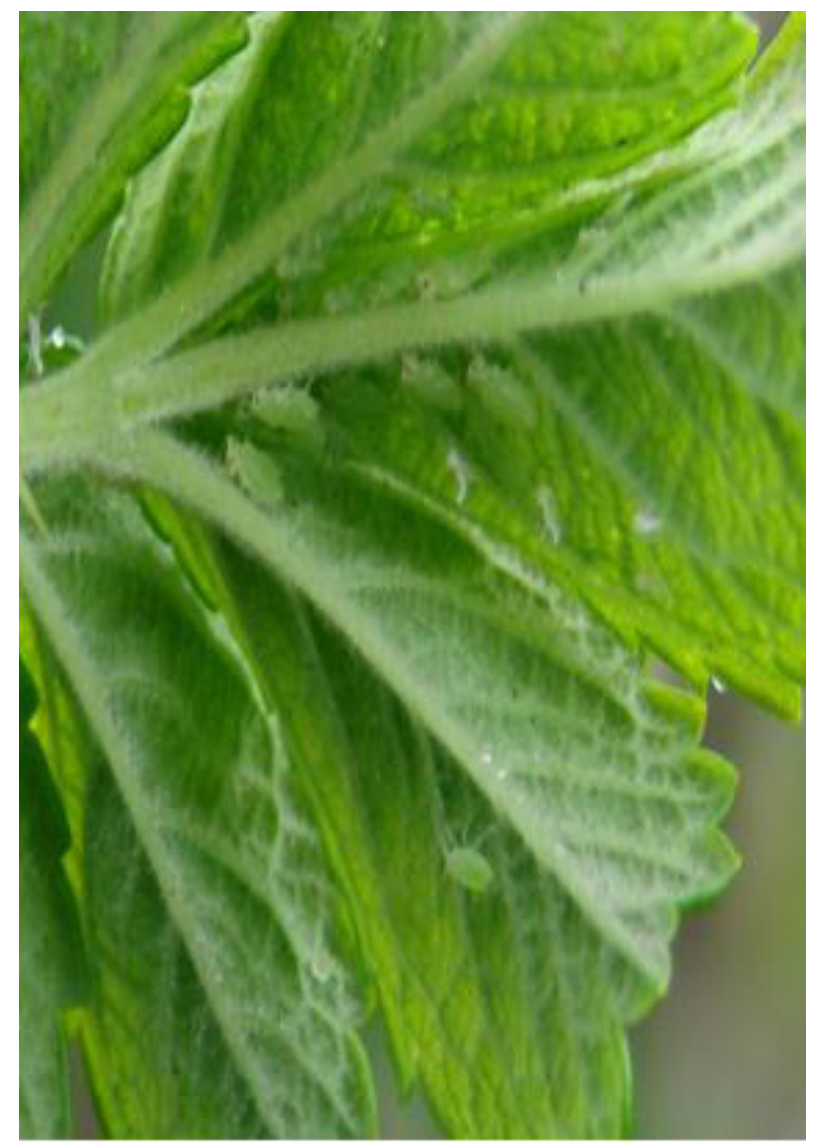

Figure 2.

M. dirhodum population on saltspray rose

Ethical approval: The conducted research is not related to either human or animal use.

\section{RESULTS}

In 2005-2007, the first fundatrices of rose grain aphid appeared on stand of saltspray rose in the second decade of April. Than the aphid population (Fundatrigeniae) intensively increased until the first decade of May. At that period, the maximum density of $M$. dirhodum population (about 130 aphid per shoot in 2005-2006 and 140 aphid per shoot in 2007) was reported. In the subsequent observation the number of aphids significantly decreased on the primary host and spring migration began (fig. 3 ).

The last two years at the observation, were characterized by an earlier appearance of the aphid pest. The first fundatrices of $M$. dirhodum on shoots of $R$. rugosa was found at the end of March. Then, the aphid population increased until the second decade of May. After reaching maximum, the number of aphids significantly decreased in the third decade of May, and in the second decade of June all aphids went.
The rose-grain aphid was the most abundant on the studied stands of saltspray rose in 2007 (fig. 3c). The lowest population of the aphid pest occurred on the saltspray rose during the last two years of observations, 2008-2009 (fig. 3d-e).

At the end of summer, winged forms of M. dirhodum migrated onto primary (winter) host plant. During all studied seasons, the autumn host-plant alternation looked similar. The first specimens of aphid were found on the bushes of saltspray rose in the second decade of September. The wingless reached a peak density on the secondary host in the second decade of September (fig. 3a-e).

The autumn population of the rose grain-aphid on saltspray rose at Siedlce stands was much lower than the spring population. There was only one exception in 2007: it did not result in higher aphid number in following spring (fig. 3c-d).

\section{DISCUSSION}

Jaśkiewicz [19] showed that $M$. dirhodum occurred on shrubs of park rose 'Grandhotel', saltspray rose, multiflorous rose and border rose. The aphid fauna colonizing roses was found in various types of city green areas such as road sites, street sites, housing estate sites and parks. In general, it six aphid species occured on the analyzed shrubs of roses including Macrosiphum rosae (L.), Chaetosiphon tetrarhodus (Walk.), Metopolophium dirhodum (Walk.), Myzaphis rosarum (Kalt.), Maculolachnus submacula (Walk.) and Longicaudus trirhodus (Walk.). Usually, M. dirhodum is very abundant on the shrubs of roses growing at street sites, while the aphid number in park sites is always smaller. Kmieć [20] found M. dirhodum on saltspray rose, multiflowered rose, park rose cv. 'Grandhotel' and different varieties of border roses. The first larvae were observed on saltspray rose in the street site in the beginning of April, what is pretty similar to our study. The aphid population was small and stayed at a similar level till the middle of May. $M$. dirhodum arrived again on the analyzed shrubs in the second decade of September, and its autumn population reached at the beginning of October. The alived aphids remained on the rose plants till the end of November. In next year, M. dirhodum appeared on saltspray rose at the street and park sites already in the second decade of March. The highest number of the insect pest was found in the second decade of April on the street sites, and the third decade on the park site. In autumn only 

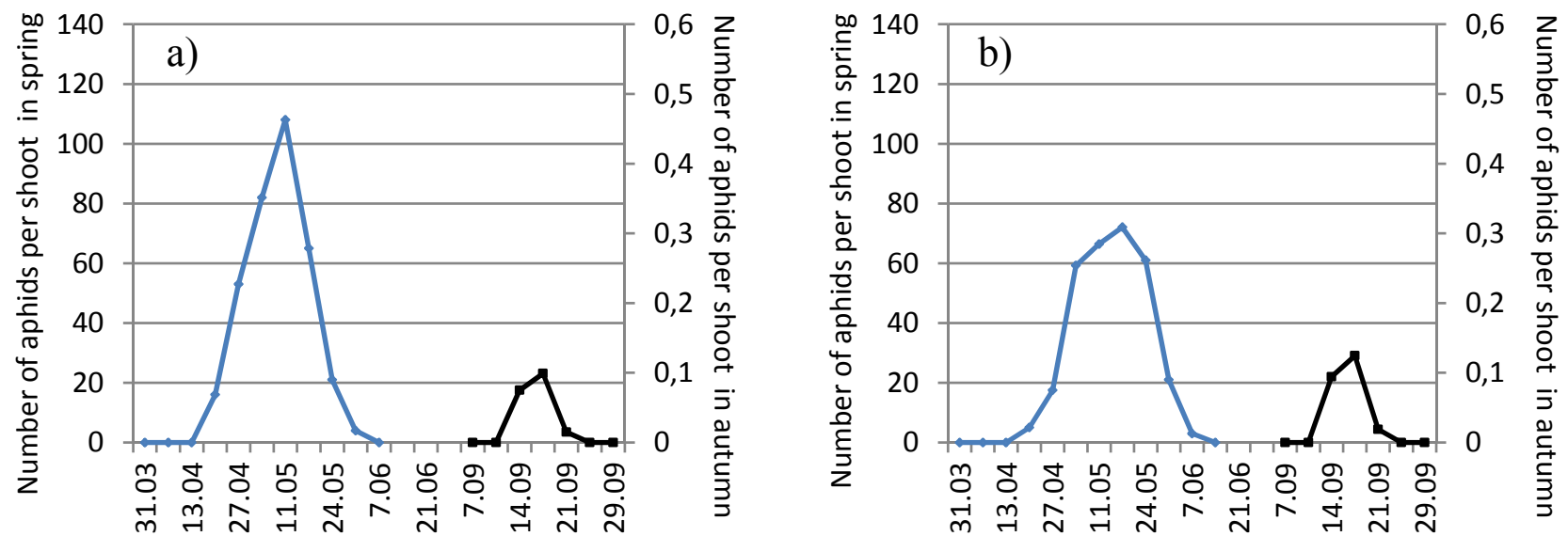

2007

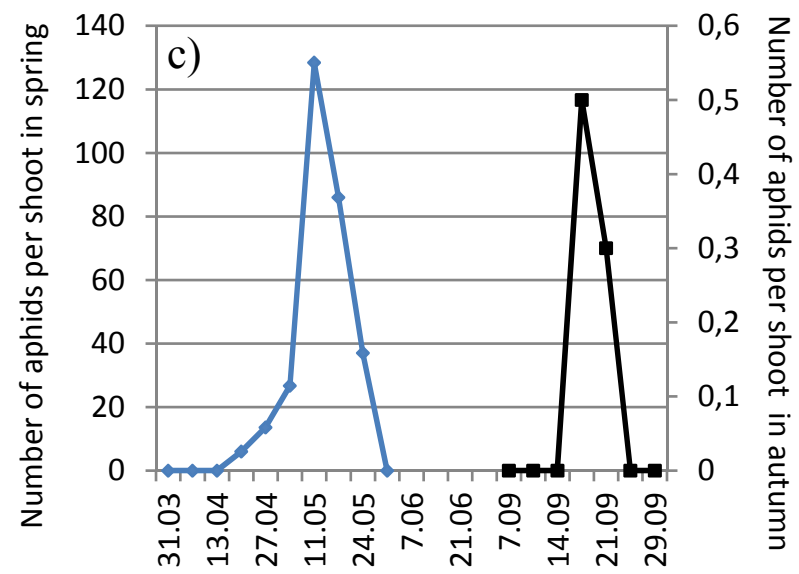

Legend:

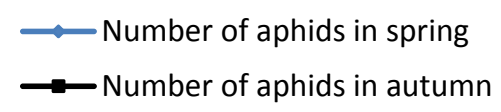

2008

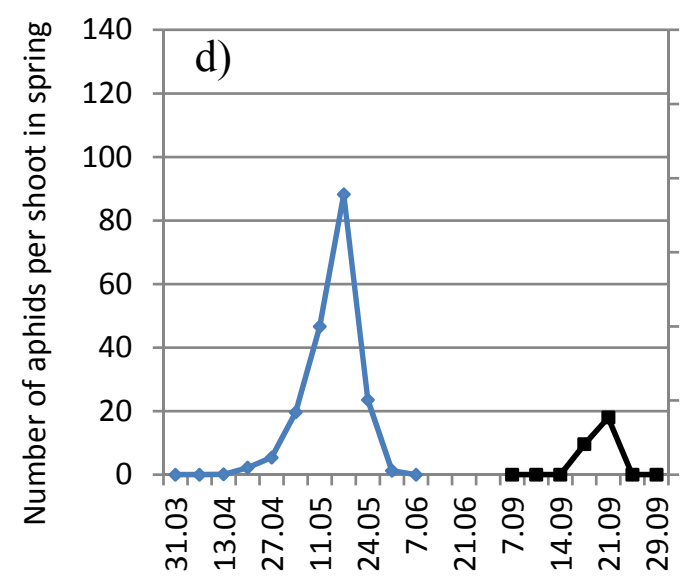

Observation period

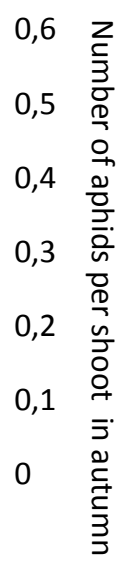

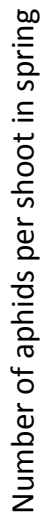

2009

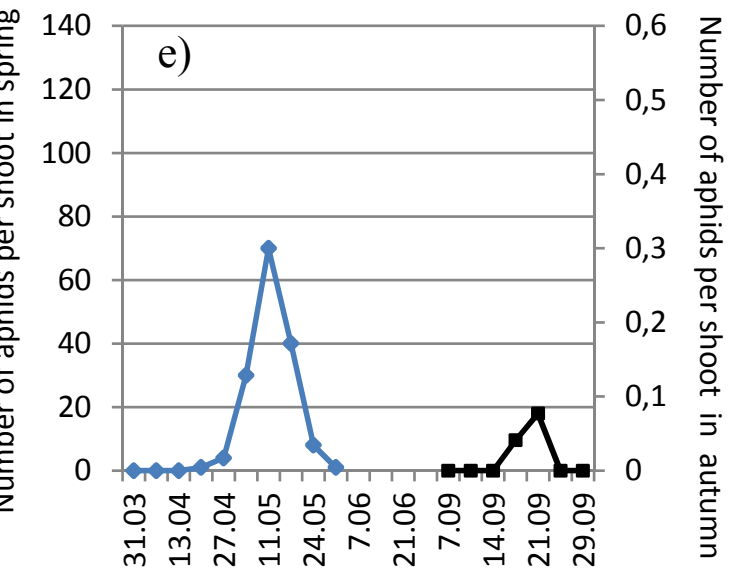

Observation period

Figure 3.

Dynamics of $M$. dirhodum on saltspray rose (R. rugosa) during 2005-2009 
scarce individuals were observed in all the sites. They remained on the shrubs from the beginning till the end of October. R. rugosa was exceptionally willingly colonized by $M$. dirhodum. Those aphids occurred there in much higher numbers as compared with other rose species.

Wojdyła et al. [21] reported that $M$. dirhodum is especially willing to colonizes the shrubs of $R$. rugosa, sometimes occurring in great numbers on the top parts of the shoots. Similarly, Krzyżanowski et al. [16] previously reported the occurrence of rose-grain aphid on saltspray rose. During this observation, the first fundatrices of the $M$. dirhodum on the R. rugosa were recorded at the end of March. The rose-grain aphid population was built-up on its primary host mostly in May. In the third decade of May numerous alatae were formed and spring migration of the aphid to the summer hosts began. Several papers reported on numerous colonizations of roses by the aphid and other stinging-sucking arthropods in the areas subjected to strong anthropopressure, for example in the sites near busy street or big industrial factories as compared to the areas much less submitted to degradation [22-27].

Ruszkowska [28] explained that aphids richness and constantly improve of diversity of farms causes the occurrence of these pests in high numbers and makes them widespread. Aphids have a number of specific developmental possibilities (e.g. short generation time, development to different morphs) which are frequently affected by changes in environmental conditions. This enables the rapid settling of new plant species by aphids in regions of different climate conditions [29]. For example, in the region of Wielkopolska there are large areas of monocultures in which $M$. dirhodum clearly dominates. In the region of Podlasie crop areas are smaller, and this results in a diversity of host plant species for cereal aphids which leads to a diversification of the aphid fauna. Thus, in the coldest region of Poland, anholocyclic aphid forms have not yet been found in Winter wheat or and Winter barley. However, M. dihodum was shown in large numbers in region of Podlasie on wild grasses e.g. Elymus repens L. and on all cereals, in spring and summer. In winter, wheat this species constituted $30 \%$ of the aphid fauna, $37 \%$ on winter barley, and $42 \%$ on maize [28]. Also Imiolczyk-Cessak et al. [30] showed this pest in the Tatra National Park region. Thus, all the data suggest that $M$. dirhodum is widely spread on roses along Poland.

\section{CONCLUSIONS}

1. M. dirhodum was observed on shrubs of R. rugosa Thunb. in all studied growing seasons.

2. The aphid is a host-alternating species, with obligatory spring and autumn migration, and thus occurring on the saltspray rose during the most of the season.

3. While the aphid population outbreaks, it might be a serious pest of saltspray rose.

Conflict of interest: Author declares no conflict of interest.

\section{REFERENCES}

1. Bruun HH. Biological flora of the British Isles, Rosa rugosa Thunb. ex Murray. J Ecol 2005; 93:441-70.

2. Bruun HH. Prospects for biocontrol of invasive Rosa rugosa. Bio Control 2006; 51:141-181.

3. Darbyshire SJ. Inventory of Canadian Agricultural Weeds 3 2003. Agriculture and Agri Food Canada. http://publications.gc.ca/Collection/ A42-100-2003E.pdf

4. Sulborska A, Weryszko-Chmielewska E. Characteristics of the secretory structures in the flowers of Rosa rugosa Thunb. Acta Agrobot 2014; 67:1324. doi: http://dx.doi.org/10.5586/aa.2014.056

5. Góra J, Lis A. Najcenniejsze olejki eteryczne. Toruń. Wyd. Uniw. Mikołaja Kopernika, 2005.

6. Feng L-G, Chen C, Sheng L-X, Liu P, Tao J, Su J-L, Zha L-Y. Comparative analysis of headspace volatiles of chinese Rosa rugosa. Molecules 2010; 15:8390-99. doi: http://dx.doi.org/10.3390/molecules 151183902010

7. Strzelecka H, Kowalski J (eds.). Encyklopedia zielarstwa i ziołolecznictwa. Warszawa. Wyd. Naukowe PWN, 2000.

8. Marinelli J. Wielka Encyklopedia Roślin. Warszawa. Świat Książki, Bertelsmann Media sp. z o.o., 2006.

9. Ochir S, Park BJ, Nishizawa M, Kanazawa T, Funaki M, Yamagishi T. Simultaneous determination of hydrolysable tannins in the petals of Rosa rugosa and allied plants. J Nat Med 2010; 64:383-7. doi: http://dx.doi.org/10.1007/s11418010-0418-5 
10. Hashidoko Y. The phytochemistry of Rosa rugosa. Phytochemistry 1996; 43:535-49. doi: http:// dx.doi.org/10.1016/0031-9422(96)00287-7

11. Youwei Z, Yonghong P. Changes in antioxidant activity in Rosa rugosa flowers at different stages of development. New Zeal J Crop Hort 2007; 35:397-401.

12. Jung H-J, Nam J-H, Choi J, Lee K-T, Park H-J. 19a-hydroxyursane-type triterpenoids: antinociceptive anti-inflammatory principles of the roots of Rosa rugosa. Biol Pharm Bull 2005; 28(1):101-4.

13. Leszczyński B. Plant allelochemicals in aphid management. In: Narwal S (ed.). Allelopathy update (II), Basic and applied aspects. Oxford \& JBH Publishing C. PVT. LTD, 1999:285-320.

14. Leszczyński B, Urbańska A, Matok H. Plant responses to cereal aphid infestation. Zesz Probl Post Nauk Rol 2006; 509:385-94.

15. Klueken AM, Hau B, Ulber B, Poehling HM. Forecasting migration of cereal aphids (Hemiptera: Aphididae) in autumn and spring. J Appl Entomol 2009; 133:328-44.

16. Krzyżanowski R, Leszczyński B, GadalińskaKrzyżanowska A, Warzecha R. Występowanie mszycy różano-trawowej na róży pomarszczonej Rosa rugosa (Thunb.). Prog Plant Prot 2009; 49:1192-1194.

17. Gadalińska-Krzyżanowska A, Krzyżanowski R, Leszczyński B, Warzecha R. Różnice w akceptacji Rosa canina (L.) i Rosa rugosa (Thunb.) przez mszycę różano-trawową Metopolophium dirhodum (Walker). Prog Plant Prot 2010; 50:16891691.

18. Blackman RL, Eastop VF. Aphid on the World's Crops. An identification and information guide. London, The Natural History Museum, 2000:1466.

19. Jaśkiewicz B. Analysis of the aphid population colonizing roses in different types of city green areas of Lublin. Acta Sci Pol, Hortorum Cultus 2005; 4:129-137.

20. Kmieć K. Dynamics of number of Metopolophium dirhodum (Walk.) (Hemiptera, Aphididae) occurring on shrubs of roses in Lublin. Acta Sci Pol., Hortorum Cultus 2006; 5(2):11-21.

21. Wojdyła A, Kamińska M, Łabanowski G, Orlikowski L. Ochrona róż. Plantpress, Kraków. 2002; 1-89.

22. Cichocka E, Sahajdak A. Liczebność i rozwój mszycy jabłoniowej na jabłoniach o różnym stopniu zanieczyszczenia środowiska. Prog Plant Prot 1996; 32(2):354-356.

23. Cichocka E, Goszczyński W, Szybczyński K. Mszyce i ich naturalni wrogowie na klonach w Warszawie. In: Barczak T, Indykiewicz P. (eds). Fauna miast. Bydgoszcz. Wyd. ATR, 1998:83-88.

24. Jaśkiewicz B, Łagowska B, Gantner M. Aphids inhabiting certain ornamental shrubs in urban conditions. Annales UMCS, sectio EEE, 2001; 9:99-107.

25. Jaworska M, Gospodarek J. Wpływ zanieczyszczenia powietrza i gleby na mszycę trzmielinowoburakową (Aphis fabae Scop.). Progr Plant Prot 2001; 41(2):395-398.

26. Lubiarz M, Cichocka E. Aphids and scale insects on pedunculate oak in two different environments, in Poleski National Park and in the neighbourhood of nitrogen fertilisers' factory (Zakłady Azotowe in Puławy). Aphids and Other Hemipterous Insects, Monograph, PAG, Rogów 2003; 9:69-91.

27. Wilkaniec B. Występowanie Eucalipterus tiliae (L.) (Homoptera: Phyllaphididae) na lipie w warunkach miejskich. Rocz. AR Pozn. CCLXXXVIII. Ogrodn. 1996; 24:85-92.

28. Ruszkowska M. Across the transformation life cycle of Rhopalosiphum padi (L.) (Homoptera: Aphidoidea): coevolution with temperature. Rozpr Nauk Inst Ochr Roślin 1990; 18:1-60.

29. Ruszkowska M. Aphids on cereals and wild grasses in different environments in Poland. Redia J Zool 2009; 92:233-235.

30. Imiolczyk-Cessak S, Depa Ł, Brożek J, Wojciechowski W. Aphids (Hemiptera: Aphidinea, of the Tatra National Park. Annals of the Upper Silesian Museum (Entomology) 2011; 20:5-74. 


\title{
Występowanie poważnego szkodnika, Metopolophium dirhodum (Walk.) na róży pomarszczonej Rosa rugosa Thunb.
}

\author{
ROBERT KRZYŻANOWSKI
}

Uniwersytet Przyrodniczo-Humanistyczny w Siedlcach

Katedra Biochemii i Biologii Molekularnej

ul. B. Prusa 12

08-110 Siedlce

e-mail: robert.krzyzanowski@uph.edu.pl

\section{Streszczenie}

Wstęp: Mszyca różano-trawowa (Metopolophium dirhodum Walke.) jest groźnym agrofagiem występującym na zbożach w Polsce. Znaczenie gospodarcze tego szkodnika w ostatnich latach wzrasta w związku z gwałtownym zwiększeniem obszaru uprawy kukurydzy na ziarno i na paszę. Mszyca różano-trawowa jest oligofagiem zimującym na krzewach róż.

Cel: Celem badań było określenie występowania tego szkodnika na żywicielu pierwotnym, jakim jest $R$. rugosa.

Metodyka: Obserwacje przeprowadzono na stanowiskach róży pomarszczonej w Parku Aleksandria, zlokalizowanych w Siedlcach, w latach 2005-2009. Każdorazowo obserwowano 50 pędów róży; w odstępach 7 dniowych od marca do wiosennej migracji szkodnika.

Wyniki: Pierwsze fundatrices $M$. dirhodum na róży pomarszczonej zaobserwowano pod koniec marca. Dynamiczny rozwój populacji przebiegał do końca maja, a maksymalne zagęszczenie populacji szkodnika występowało w połowie maja.

Wnioski: Mszyca różano-trawowa może być groźnym szkodnikiem róży pomarszczonej w latach masowych pojawów.

Słowa kluczowe: mszyca różano-trawowa, Metopoliphium dirhodum, róża pomarszczona, Rosa rugosa 